\title{
A MEZŐGAZDASÁGI DIVERZIFIKÁCIÓHOZ KÖTŐDŐ TÁMOGATÁSOK MAGYARORSZÁGON
}

SUBSIDIES RELATED TO THE DIVERSIFICATION IN AGRICULTURE IN HUNGARY

\author{
Áldorfainé Czabadai Lilla \\ tanársegéd \\ Gazdaság- és Társadalomtudományi Kar, Szent István Egyetem \\ E-mail: Aldorfaine.Czabadai.Lilla@gtk.szie.hu
}

\section{Összefoglalás}

Az elmúlt években Magyarország nagy összegü vidékfejlesztési támogatásokban részesült. Számos tanulmány bizonyítja, hogy az Európai Mezőgazdasági és Vidékfejlesztési Alap által kifizetett támogatások sok esetben hatásosnak bizonyultak, azonban a nem mezőgazdasági tevékenységi célú diverzifikálásra szánt EU-források hasznosulása Magyarországon nem volt hatékony az utóbbi években. Kutatásom során azt szándékoztam feltárni, hogy mely települések éltek a lehetőséggel és az igénybe vett támogatások okoztak valamilyen változást a vidéki térségekben.

\begin{abstract}
In the past few years Hungary received a huge amount of rural development subsidies. Several studies show that the aids paid by the Agricultural and Rural Development Agency was quite efficient in many cases, but the utilization of the non-agricultural diversification subsidies were not effective. In my research I examined the effect of the less-known supports especially the impact of the subsidy for diversification into non-agricultural activities. As a result I would like to explore which Hungarian settlements took the opportunity and if so, whether this action cause an evident change in the rural areas?
\end{abstract}

Kulcsszavak: vidékfejlesztés, támogatások, hatás, diverzifikáció, mezőgazdaság JEL besorolás: R10

LCC: S539

\section{Bevezetés}

Hazánk a mezőgazdasághoz és a vidékfejlesztéshez kapcsolódó Európai uniós támogatások első nagy hullámában az Új Magyarország Vidékfejlesztési Program keretein belül részesült. 2007 és 2013 között Magyarország az EMVA jóvoltából mintegy 1,300 milliárd forintnyi támogatás felhasználására volt jogosult. Az EU-s prioritásokhoz kapcsolódva az ÚMVP négy támogatási tengelyt fogalmazott meg.

- I. tengely: A minőség és a hozzáadott érték növelése a mező- és erdőgazdaságban, valamint az élelmiszer-feldolgozásban;

- II. tengely: A földhasználat racionalizálása a környezeti és természeti értékek figyelembevételével;

- III. tengely: A vidéki foglalkoztatás bővítése, a tevékenységek diverzifikálása;

- IV. tengely: Helyi közösségek fejlesztése, LEADER (EU Pályázati Portál, 2016)

A támogatások összegét az 1. táblázat mutatja. 
1. táblázat: Az egyes tengelyekhez tartozó támogatások

\begin{tabular}{|c|c|c|}
\hline I. tengely & $2.388 .289 .459 . €$ & $649.853 .561 .793 . \mathrm{Ft}$ \\
\cline { 1 - 2 } II. tengely & $1.697 .679 .988 . €$ & $461.938 .724 .734 . \mathrm{Ft}$ \\
\cline { 1 - 1 } III. tengely & $691.806 .587 . €$ & $188.240 .572 .323 . \mathrm{Ft}$ \\
\cline { 1 - 2 } IV. tengely & $205.860 .358 . €$ & $56.014 .603 .412 . \mathrm{Ft}$ \\
\cline { 1 - 2 } TS keret & $\mathbf{5 . 2 5 6 . 8 1 3 . 3 6 2 . €}$ & $\mathbf{1 . 4 3 0 . 3 7 8 . 9 1 5 . 8 0 0 . F t}$ \\
\hline Összesen &
\end{tabular}

Forrás: Németh, 2012

A támogatások elköltésének hatékonyságáról és az előzetesen kitüzött célok megvalósulásáról 2011-ben félidős jelentés készült. Az értékelés (Vidék és Gazdaság, 2011) vegyes eredményekröl számolt be. A források 53\%-át kitevő I. tengely által megvalósult fejlesztések főként a mezőgazdasági üzemek korszerüsítése - pontszerüségük miatt nem gyakoroltak mérhető hatást a gazdaságra, vagy nem megfelelő ütemben haladtak (állattartó telepek korszerüsítése).

A II. tengely két fő komponense az AKG és a MTÉT erőteljes forrás-koncentrációt mutatott és sok szakértő azt kritizálta, hogy többen a kompenzációs támogatás miatt vállalták a megvalósításukat. A III. tengely intézkedésire (a vidéki gazdaság diverzifikálása, a vidéki vállalkozások beruházásainak támogatása, a vidéki települések szolgáltatás- és infrastruktúra fejlesztése, településkép-fejlesztés, az épített és természeti örökség megörzése) az EU-s források csupán 13\%-át szánták, amely főként a szolgáltatás-fejlesztő intézkedések (falu-vagy tanyagondnoki szolgálat és integrált közösségi szórakoztató terek) megvalósulását jelentette. A mikro-vállalkozások fejlesztését és a turisztikai beruházások támogatását célzó források hatékony megvalósulását a változó feltételrendszer, a bonyolult adminisztráció, az előleg-kérés lehetőségének hiánya és a pályázatok hosszú átfutási ideje is akadályozta. A településkép javítása a legtöbb település esetében parkok és játszóterek épülését, templomok felújítását jelentette, amely közvetetten ugyan, de hozzájárult a lakosság életminőségének növeléséhez. E tengelyhez kapcsolódik a Helyi Akciócsoportok kialakítása, amelyek számos változtatás után a 2014-2020-as programozási időszakban is tovább müködnek összefogva a civil társadalmat, az önkormányzatot és a helyi vállalkozásokat, azok érdekeit.

AZ ÚMVP IV. tengelye, a LEADER arra hivatott, hogy a tengelyek közötti integrált fejlesztéseket alulról jövő kezdeményezések segítségével, az önkormányzati müködés hatékonyabbá tételével aktívan támogassa. A fent nevezett célok elérését azonban nehezítette a tengelyek közötti átjárhatatlanság és a bonyolult adminisztráció, melyet más tanulmányok is megerősítenek (Kassai-Ritter, 2011; Ritter et al, 2011). Dr. Maácz Miklós, a Vidékfejlesztési Minisztérium Vidékfejlesztési osztályának vezetője 2013-ban a Darányi Ignác Tervvel összhangban három fó változtatást mutatott be. Az első a III. tengelyen belül a nem mezőgazdasági tevékenységgé történő diverzifikálás forrásainak átcsoportosítása a vidéki gazdaság és lakosság számára nyújtott alapszolgáltatások intézkedésbe.

Elöbbi jogcím közpénzböl való hozzájárulását csökkentették, utóbbiét pedig növelték. A másik fontos módosítás a mikrovállalkozások létrehozására és fejlesztésére szánt összegek átcsoportosítása, melynek célja minél több kedvezményezett turisztikai célú tevékenység fejlesztése volt.

A turisztikai tevékenységek ösztönzésére a közpénzekből való hozzájárulás mértékét növelték. A IV. tengelyen belül a környezet/földgazdálkodás, valamint az életminőség/diverzifikáció intézkedések forrásait allokálták a versenyképességet célzó programpontok megvalósítására. 
A III. tengelybe tartozó nem mezőgazdasági tevékenységgé történő diverzifikálás intézkedés népszerütlenségének oka a szabályozási keretek bonyolultsága mellett a fogalmi háttér ismeretlensége is lehetett. Ehhez kapcsolódóan szeretném felvázolni a diverzifikációhoz köthető fogalmi háttér egyes elemeit.

A diverzifikáció kifejezés önmagában is többféle jelentést hordoz. Az idegen szavak és kifejezések szótárából (Bakos, 2002) a müködési kör kiterjesztése, illetve a több lábon állás magyarázatokat érdemes kiemelni. Szakál (2000) szerint a diverzifikáció a legegyszerübb esetben az ágazatok vagy a tevékenységek számának növekedését jelenti. Megkülönböztet vertikális (valamely meglévő tevékenység termékpályájához kapcsolódó tevékenység termelési szerkezetbe történő bevonása), teljes termékpálya típusú (a vállalat olyan új tevékenységeket von be a termelési szerkezetbe, amelyek a meglévő eszközökkel vagy technológiákkal megvalósíthatók) és oldalirányú (olyan teljesen új tevékenység, amely eltér az eredeti profiltól és új igényeket elégít ki).

A diverzifikáció előnye Magda (2003) szerint a tevékenységek kiegészítő jellege, ezáltal a munkaerő hatékonyabb kihasználása is lehet. További pozitívum, hogy a jövedelembiztonság nem egyetlen termék hozamának alakulásától függ.

Összefoglalva tehát az agrárgazdaságtan szokásos értelmezésében a diverzifikáció a mezőgazdaságban elsősorban a termelési szerkezetbővítést jelenti (Hamza, 2011). Az 1996-os corki konferencia óta azonban a diverzifikáció és a multifunkcionalitás fogalmában sok közös elem fedezhetö fel.

Az integrált és sokoldalú (multifunkcionális) mezőgazdaságban szerves egységet alkot a hagyományos értelemben vett mezőgazdaság, az erdészet, az akvakultúra, a vadászat, az élelmiszer-feldolgozás (Szakál, 2000), amelyek hozzájárulnak a táj- és a környezetvédelemhez, a megújítható természeti erőforrások fenntartásához, a biodiverzitás megőrzéséhez, valamint a vidék társadalmi-gazdasági életképességének fenntartásához. Fehér (2005) szerint a diverzifikáció a multifunkcionalitástól eltérően a mezőgazdaságtól eltérő tevékenységre vonatkozik. A nem mezőgazdasági tevékenységgé történő diverzifikáció intézkedésének értelmezése kapcsán többféle lehetőséggel találkozhatunk. Ilyen például a „soktevékenységüség” (pluriactivity) és a farmdiverzifikáció, amely hazánkban is egyre elterjedtebb fogalom.

Az Eurostat Gazdaságszerkezeti Összeírásának (Farm Structure Survey, FSS) definíciója szerint ,a „pluriactivity” fogalma alá tartozik a saját gazdaságban végzett minden, nem mezőgazdasági tevékenység, (mint pl. a turistáknak történő szállásadás) vagy más gazdaságban végzett díjazott tevékenység, illetve nem mezőgazdasági vállalkozás alkalmazásában történő munkavégzés. A „diverzifikáció” fogalma alatt pedig minden olyan tevékenységet kell érteni, amely nem tartozik a hagyományos mezőgazdasági tevékenységek közé, ugyanakkor közvetlenül kapcsolódik a gazdasághoz pl. használja a gazdaság erőforrásait vagy termékeit" (Hamza, 2011). A „pluriactivity” esetében az FSS adatgyüjtése az egyéni gazdaságok vezetőire, azok házastársára, családtagjaira vonatkozik, és azt méri fel, hogy a gazdaságon kívül fő vagy kiegészítő formában végez-e más jövedelemszerző tevékenységet. Ezzel ellentétben a farmdiverzifikációra vonatkozó adatgyüjtés az összes gazdaságra (gazdasági szervezetekre is) vonatkozik és azt méri fel, hogy van-e a gazdaságban végzett nem mezőgazdasági tevékenység. 
Ezek a felmért tevékenységek a Bizottság 1444/2002/EK rendelete alapján az alábbiak lehetnek:

- Mezőgazdasági termék-feldolgozás: húsfeldolgozás, sajt készítés, bortermelés, stb. fogyasztóknak történő közvetlen értékesítés

- Szerződéses munkavégzés: Pl. hóeltakarítás, szállítás,

- tájfenntartási munkák, mezőgazdasági és környezetvédelmi szolgáltatás.

- Akvakultúra: hal- és ráktermelés a gazdaságon belül.

- Megújuló energia termelés: megújuló energiát termel piacra, továbbá mezőgazdasági termékek, szalma, fa eladása energiatermelés céljára.

- Turizmus: minden turisztikai tevékenység, szállásadási szolgáltatás, gazdaság turisztikai bemutatása, sport, rekreáció, stb., amennyiben a terület, az épületek, vagy más hasznosított erőforrások a gazdasághoz tartoznak.

- Kézmüvesség: olyan tevékenység, amit a gazdaságban a gazdálkodó, vagy családtagja, vagy családi munkaerőn kívüli munkaerő végez.

- Fafeldolgozás: nyersfa gazdaságban történő feldolgozása értékesítés céljára (fürészáru).

A KSH (2000) két csoportba sorolja a nem mezőgazdasági tevékenységeket. Az egyik a mezőgazdasági termékek feldolgozása, a másik az egyéb másodlagos tevékenységek, amelyek a következőket foglalják magukba, melyek szorosan kapcsolódnak a vidékfejlesztéshez kapcsolódó földhasználathoz is (Nagy - Káposzta, 2016):

- agroturisztikai tevékenységek (szállásadás, étkeztetés),

- a gazdaságban termelt termékek közvetlen értékesítése,

- sport és rekreációs szolgáltatás a gazdaság területén (golf, lovaglás, horgászat),

- harmadik fél részére történő szolgáltatás nyújtás (mezőgazdasági gépek bérbeadása, öntözés, tanácsadás, termény tárolás, szállítás),

- tájgazdálkodási, tájfenntartási szolgáltatások (kaszálás, sövénynyírás, hóeltakarítás),

- halgazdálkodás,

- egyéb tevékenységek, amelyek a gazdaság földjének és eszközeinek használatával járnak.

Látható, hogy a nem mezőgazdasági tevékenységek meghatározásaiban, definícióiban számos elem mutat hasonlóságot. Ennek megfelelően az ÚMVP III tengelyében szereplő nem mezőgazdasági tevékenységgé történő diverzifikációra vonatkozó 129/2012. (XII. 17.) számú VM rendelet is meghatározta a támogatható tevékenységek körét. A nem mezőgazdasági tevékenységgé történő diverzifikálást az értelmező rendelkezésekben olyan tevékenység fejlesztéseként definiálja, amely az ügyfél nem mezőgazdasági tevékenységéhez kapcsolódó jövedelemtermelő tevékenységeinek megvalósítását segíti elő.

A rendelet kiköti, hogy a gazdálkodó bizonyos típusú szálláshely fejlesztéseket csak a gazdaságon belül, mezőgazdasági tevékenységéhez, a mezőgazdasági tevékenységéhez kapcsolódó földterületéhez és mezőgazdasági hasznosítású épületeihez kapcsolódóan valósíthat meg. A rendelet meghatározza továbbá azokat a turisztikai szolgáltatás fejlesztéseket, amelyek kapcsolódhatnak az intézkedéshez:

- agroturisztikai szolgáltató tevékenység,

- lovas turisztikai szolgáltatás,

- vadászturizmus,

- erdei turizmus,

- horgászturizmus,

- vízi turizmus,

- borturizmus. 
A fent említett definíciókkal való hasonlóság ismét szembetünő, de a rendelet a turisztikai tevékenységeken kívül más típusú nem mezőgazdasági tevékenységeket (pl. hozzáadott értéknövelés, élelmiszer-feldolgozás stb.) nem említ.

A bevezetésben már szóltunk róla, hogy ezen típusú intézkedésnek nem volt igazán nagy a népszerüsége, az erre szánt forrásokat a vidéki gazdaság szolgáltatásfejlesztésébe csoportosították át. A másik átalakítás a mikrovállalkozások fejlesztésére szánt összegek a turisztikai tevékenységek ösztönzésére történő átfordítása volt, melyet a 104/2013. (XI. 14.) VM rendelet szabályoz. Már az értelmező rendelkezésekben olyan fogalmak meghatározásával találkozhatunk, amelyek lefedik a nem mezőgazdasági tevékenységgé történő diverzifikáció definícióit is, mint például:

1. agroturisztikai szolgáltató tevékenység: szálláshely szolgáltatáshoz nem kötődő

a) a helyi, vagy saját népmüvészeti, néprajzi, kézmüves, építészeti és kulturális értékek, örökségek, termékek bemutatása,

b) a falusi élethez, környezethez és munkakultúrához kapcsolódó hagyományok, tevékenységek bemutatása,

c) falusias, tanyasias vagy vidéki környezetben a házi élelmiszerekhez és gasztronómiai hagyományokhoz kapcsolódó tevékenységek bemutatása, és az elkészített élelmiszerek felkínálása helyben fogyasztásra, valamint értékesítésre turisztikai és vendéglátói céllal a gazdaság területén,

d) a helyi gazdálkodási módok, termelési szokások bemutatása;

2. borturizmus: borvidékhez tartozó településen az adott borvidéken termelt borok értékesítésére és kóstoltatására alkalmas helyiségek kialakítása;

3. egyéb szálláshely

4. erdei turizmus

5. falusi szálláshely

6. falusi turizmus

7. horgászturizmus

8. konferenciaturizmus

9. lovas turisztikai szolgáltatás

10. rekreációs szolgáltatás

11. vadászturizmus

12. vízi turizmus

Jól látható, hogy a támogatott tevékenységek köre részben a fogalmi átfedések miatt nagyon hasonló a nem mezőgazdasági tevékenységgé történő diverzifikáció esetében felsorolt tevékenységekhez.

Később a Darányi Ignác Terv (mint a Nemzeti Vidékstratégia 2012-2020 keretprogramja) főbb céljainak bemutatása során Németh Tibor (2012) a Mezőgazdasági és Vidékfejlesztési Hivatal Békés megyei Kirendeltség- vezetője előadásában is kiemelte a mezőgazdaságon kívüli, azt kiegészítő tevékenységek fontosságát. A Nemzeti Vidékstratégia és a Darányi Ignác Terv célkitüzéseivel kapcsolatban fontos megemlíteni, hogy a hazai vidéki terület nagy része az EUs támogatások miatt kikerültek a hazai programok és források kedvezményezettjeinek köréböl. A már említett okok mellett ez is fékezhette a fejlesztési forrásoktól elvárt hatásokat.

A hatások mérésével (mérhetőségével) összefüggésben Hamza (2011) megállapítja, hogy több uniós országban, miként hazánkban sem mérik sem a mezőgazdasági termékek feldolgozásának, sem az egyéb másodlagos tevékenységek kibocsátását. Ennek eredményeképpen a felhasznált uniós támogatások gazdaságra gyakorolt hatásai is nehezen mutathatók ki. Az irodalmi áttekintésben leírt támogatási irányzatok azt mutatják, hogy a nem 
mezőgazdasági tevékenységgé történő diverzifikálás fogalmának értelmezése sok esetben különböző (alternatív) turisztikai tevékenységek megvalósítását jelenti.

\section{Anyag és módszertan}

Kutatásomban a III. tengely és az ahhoz kapcsolódó két intézkedés vizsgálatára - a nem mezőgazdasági tevékenységgé történő diverzifikálásra, valamint a turisztikai tevékenységek ösztönzésének támogatására fókuszáltam. A Mezőgazdasági és Vidékfejlesztési Hivatal által szolgáltatott adatokat az Országos Területfejlesztési és Területrendezési Információs Rendszerből 2013, 2014 és 2015 évekre települési szinten gyüjtöttem le. Hosszabb időtávú vizsgálatra az adatok hiánya miatt nem volt lehetőség. Az általam vizsgált két támogatási forma esetében ugyanis értékelhető adatok 2013-töl álltak rendelkezésre.

Mind a nem mezőgazdasági tevékenységgé történő diverzifikáció, mind a turisztikai tevékenységek ösztönzése esetében az EMVA által kifizetett kérelmek összege (Ft/település) került legyüjtésre, melynek oka, hogy az elfogadott, vagy támogatott kérelmek száma az adott évben még nem jelenti a támogatás realizálódását a településen.

A vizsgált három évben a kifizetett kérelmek összegét az összes településen aggregáltam, majd az eredményeket a Geomarket program segítségével térképesen is megjelenítettem. Az osztályközös térképi ábrázolással nem csak a támogatások esetleges területi összefüggései, hanem a támogatások mértékében rejlö különbségek is szemléletesebbek.

A szürke és a fekete különböző árnyalati jelzik az elnyert támogatások összege közötti különbségeket. A skálázás alapvetően 0-100-ig terjed, húsz millió forintos közökkel. Az adatok között voltak ugyan negatív (valószínüleg vissza kellett fizetni a támogatást) és kiugróan magas értékek, ez azonban nem befolyásolta az végleges eredményeket.

\section{Eredmények}

A nem mezőgazdasági tevékenységgé történő diverzifikáció intézkedésre 2013 és 2015 között kifizetett kérelmek térképi megjelenítését az 1. ábra mutatja. A vizsgált három év alatt támogatásban 225 település részesült.

A fekete színnel jelölt térségek nyerték el a legmagasabb összegeket. A legtöbb pénzt, több mint 455 millió forintot Bócsa település nyerte. A következő sávba tartozik számos nagyváros: Debrecen, Nyíregyháza, Eger, Miskolc, Szeged és Szombathely, de szintén magas támogatási összegekkel találjuk a sorban a tradicionálisan mezőgazdasági területen lévő településeket, például: Baja, Kiskőrös, Kiskunfélegyháza, Nagykőrös.

A fehéren maradt részek a támogatásnak e fajtájában (ha pályáztak is) egyáltalán nem részesültek. Ez alól Budapest kivételt jelent, a fóvárost az adatok torzító hatása miatt kihagytam a vizsgálatból. 


\section{1. ábra: A nem mezőgazdasági tevékenységgé történő diverzifikáció}

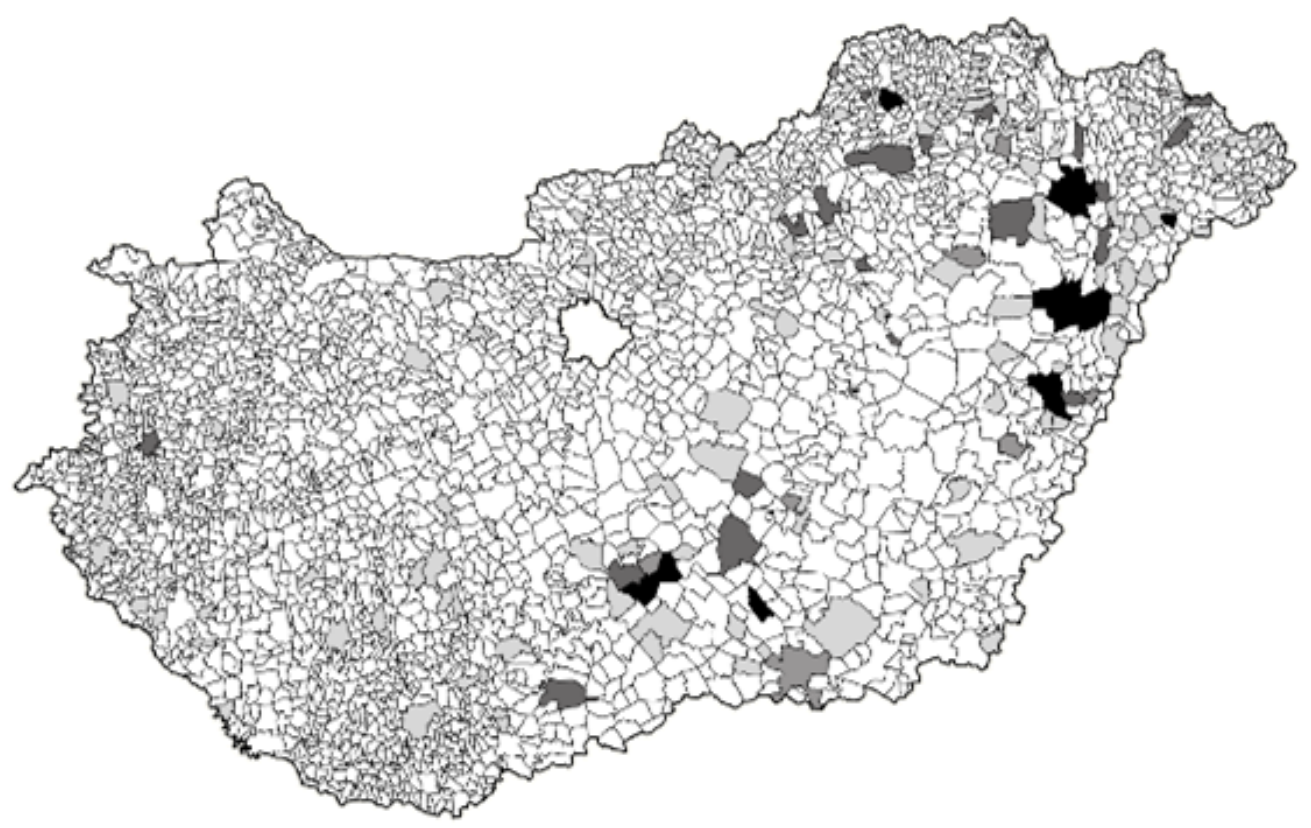

Forrás: TeIR adatok alapján saját szerkesztés a Geomarket program segitségével, 2016

A 2. ábrán a turisztikai tevékenységek ösztönzésére kifizetett kérelmek 2013 és 2015 közötti időszakban összesített képe látható. Összességében 811 település nyert pályázatot a turisztikai szolgáltatásaik bővítésére, fejlesztésére. A legmagasabb összeget Nyíregyháza érte el közel 540 millió forintos támogatással. A 300 millió forintos határt Miskolc, Debrecen és Békésszentandrás is meghaladta. 200 millió forintnál több támogatásban részesült Szarvas, Győr és Kaposvár és további 25 település nyert el 100 millió forintot meghaladó összeget. A főváros adatait az előző elemzéshez hasonlóan szintén kihagytam a vizsgálatból.

\section{2. ábra: A turisztikai tevékenységek ösztönzése}

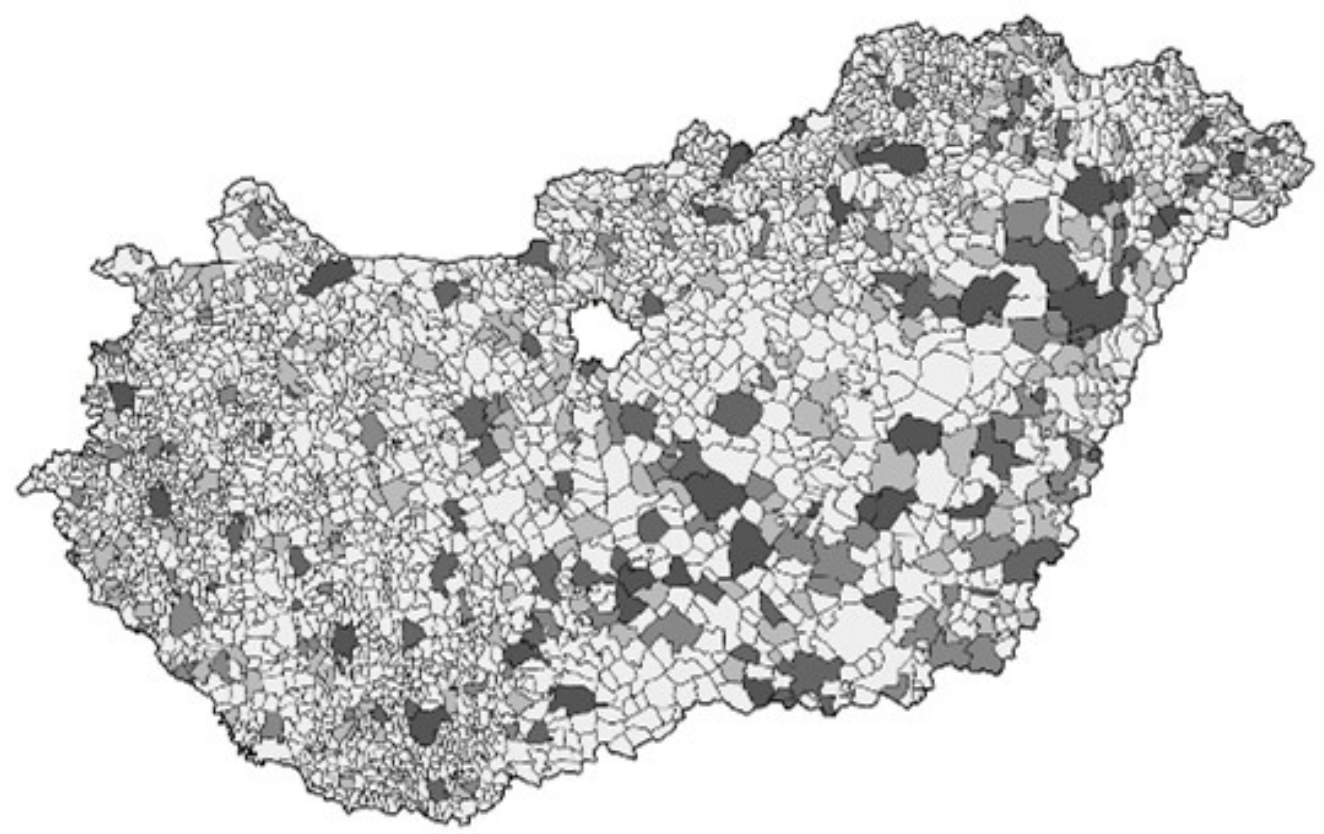

Forrás: TeIR adatok alapján saját szerkesztés a Geomarket program segítségével, 2016 
Az eredmények teljessé tételének, a mérhetőség kérdésének körüljárása érdekében felvázoltam néhány korábbi kutatási eredményt is. A turizmus hatásait a térgazdaság fejlödését már többen is vizsgálták (Nagy, 2016; Káposzta et al, 2016).

Az Új Magyarország Fejlesztési Terv - Új Széchenyi Terv gazdaságfejlesztéshez kapcsolódó pályázati forrásait elemezve arra jutottak, hogy a kistérségek többsége 40 millió Ft és 200 millió Ft közötti támogatást kapott, ezen belül ,azok a kistérségek, amelyek fejlődést értek el 2007 ről 2013-ra kivétel nélkül legalább 40 millió $\mathrm{Ft}$ gazdaságfejlesztési támogatáshoz is jutottak a turisztikai források mellett. Azok a kistérségek, amelyek támogatása nem érte el a 40 millió Ftot 1.000 lakosra vetítve, azok jellemzően azok a területek, amelyekben a fejlödés nem észlelhető idegenforgalmi potenciál szempontjából a turisztikai beruházások allokációja ellenére sem.” (Nagy, 2016).

Megvizsgálták azoknak a kistérségeknek az elhelyezkedését, amelyek (előzetes számításaik alapján) az alacsony potenciállal rendelkező kategóriából a közepesen alacsony kategóriába tudtak fejlődni 2007 és 2013 között, melynek eredményét a 3. ábra mutatja.

\section{3. ábra: 2007-ben alacsony turisztikai potenciállal rendelkező kistérségek 2013-ra elért eredményei}
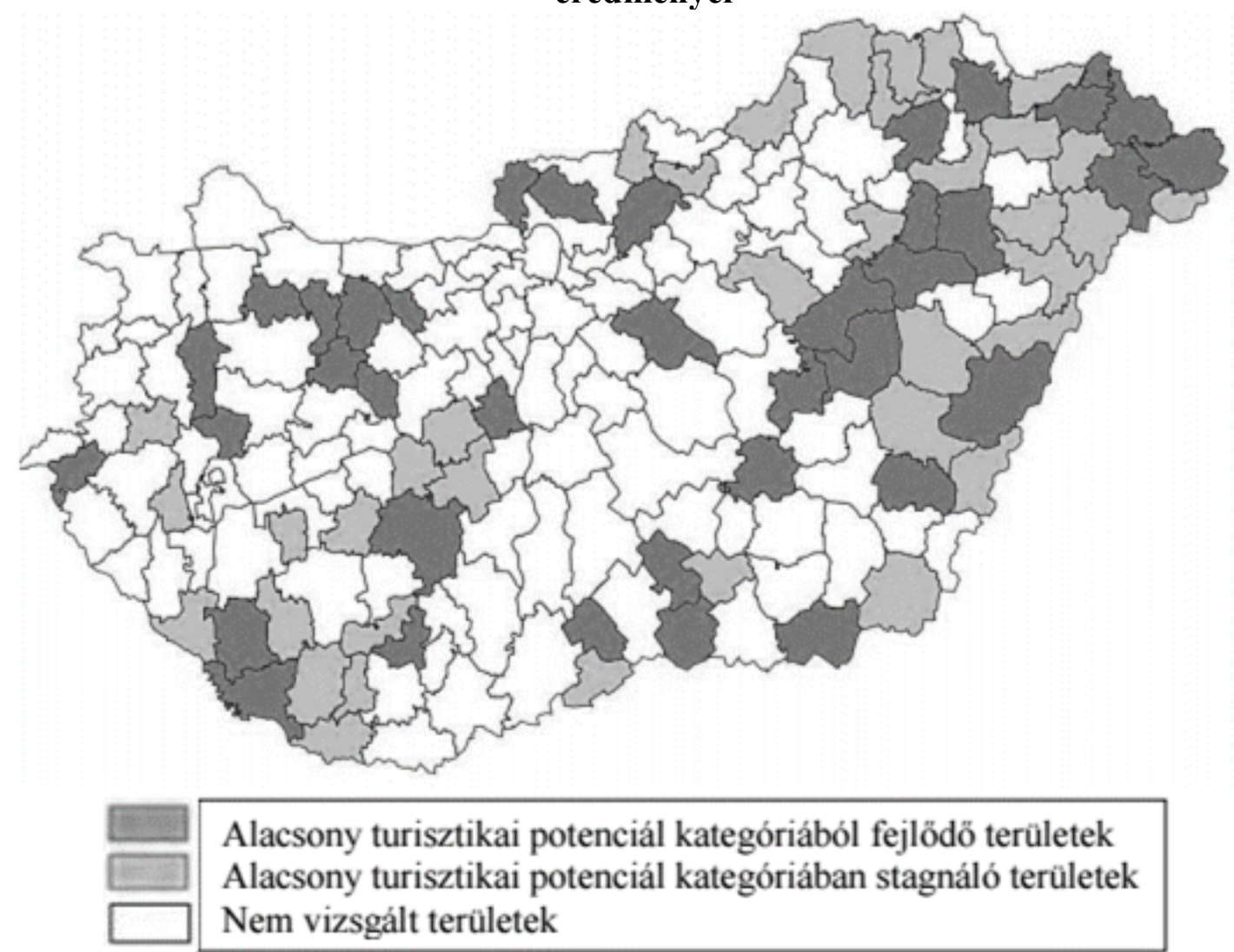

Forrás: Nagy, 2016

Ha összehasonlítjuk a 2. és 3. ábrát számos hasonlóságot fedezhetünk fel a fejlődésre képes térségek és a turisztikai tevékenységek ösztönzésére támogatást nyert települések elhelyezkedése között. 
A leghátrányosabb helyzetü térségekben is figyelhetünk meg olyan településeket, amelyek pályázati, fejlődési potenciállal rendelkeznek. Ezt az eredményt támasztja alá néhány hasonló kutatás is (Ritter et al, 2012; Tánczos et al, 2012).

\section{Következtetések}

Az eredmények alapján jól látható, hogy a nem mezőgazdasági tevékenységgé történő diverzifikáció intézkedéshez kötődő pályázatok a megvalósulás és a hatékonyság szempontjából nem tekinthetők sikertörténetnek Magyarországon. A kifizetett kérelmek száma (összege) és területi eloszlása is arra enged következtetni, hogy a pályázati feltételek bonyolultak, félreérthetőek voltak, a megvalósításra szánt idő kevés volt, megfelelő humánerőforrás hiányában a megírás sikertelen volt.

A pályázati kiírás a diverzifikációt a turizmus irányába vezette (agroturizmus, falusi turizmus stb.) miközben például a hozzáadott értéknövelés háttérbe került. Az ily módon a támogatásból kimaradó települések a kettős finanszírozás elkerülése végett a hazai fejlesztési forrásokat sem vehették igénybe. A kisszámú sikeres pályázat miatt a megvalósulás hatékonysága is nehezen mérhető. Az intézkedésből a szolgáltatásfejlesztésbe átcsoportosított támogatások sokkal látványosabb eredményt hoztak (például IKSZT-ek), de ezek hasznossága is csak közvetetten mérhető.

A turisztikai tevékenységek ösztönzése elnevezésü intézkedés látványosabb eredményeket hozott, igaz elemei nagy hasonlóságot mutatnak a nem mezőgazdasági tevékenységgé történő diverzifikálás tevékenységeivel. Az előző intézkedéshez képest majdnem négyszer annyi település járt sikerrel a pályázati folyamatban, 10 millió forint alatti támogatás nem is igazán fordult elö.

Mind a két vizsgált esetben elmondható, hogy a mérhetőség a turisztikai mutatószámok bevonása nélkül nem lehetséges. A közvetlenül a mezőgazdasághoz kapcsolódó támogatások indikátorai statisztikailag sokkal egyszerübben kimutathatók és hozzáférhetők (például az erdők területének, az állatlétszám vagy egyes növények vetésterületének növekedése), míg a nem mezőgazdasági tevékenységgé történő diverzifikációt tekintve ez nem mondható el. A már sokszor említett turisztikai mutatók (például a falusi szálláshelyek száma) adatai megtalálhatók ugyan, de például a hozzáadott érték, vagy helyben eladott kézműves termékek száma települési szinten már abszolút nem elérhető.

A megvalósítás hatékonyságának növelése céljából érdemes volna hazai szinten olyan célzott pályázatokat kiírni, amelynek céljai közérthetőek és hatékonyan szolgálják a vidéken élök igényeit, szükségleteit. Javaslatként említeném még a turisztikai tevékenységek ösztönzését és a nem mezőgazdasági tevékenységgé történő diverzifikálás intézkedéseket erőteljesebben elkülöníteni (habár 2016 szeptemberétől utóbbihoz kapcsolódó pályázatok újranyílnak) annak érdekében, hogy a mezőgazdaság diverzifikációja ne csupán alternatív turisztikai szolgáltatásokat jelentsen.

A forrásfelhasználás hatékonyságának mérhetősége kapcsán fontos volna már a pályázatokban olyan indikátorok megjelölését (bár ez már bevált EU-s gyakorlat) kérni a pályázótól, amelyekkel valóban tudja mérni, később bizonyítani a fejlődést. 


\section{Irodalomjegyzék}

1. 104/2013. (XI. 14.) VM rendelet

2. 129/2012. (XII. 17.) számú VM rendelet

3. Bakos F. (2002): Idegen szavak és kifejezések szótára Akadémiai Kiadó. p.148.

4. Bogárdi T. - Molnár M. (2014): The barriers to economic development through the example of a Hungarian internal periphery Vestnik Apk Stavropolya / Agricultural Bulletin of Stavropol Region 1:(1) pp. 52-55.

5. EU pályázati portál (2016): http://eupalyazatiportal.hu/uj_magyarorszag_videkfejlesztesi_program_umvp_2007_20 13/ (letöltve: 2016. augusztus15.)

6. Európai Bizottság 1444/2002/EK rendelet

7. Fehér A. (2005): A vidékgazdaság és a mezőgazdaság. Budapest.

8. Hamza E. (2011): A diverzifikáció föbb összefüggései a mezőgazdasági Vállalkozásokban, Doktori értekezés, Szent István Egyetem, Gazdálkodás- és Szervezéstudományok Doktori Iskola

9. Káposzta J., - Nagy A. - Nagy H. (2016): The impact of tourism development policy on the regions of Hungary, REGIONAL ECONOMY. SOUTH OF RUSSIA 11:(1) pp. 1017.

10. Kassai, Zs. - Ritter, K. (2011): Helyi vidékfejlesztési programok a hátrányos helyzetü vidéki térségekben. In: Gazdálkodás, 55 (4), pp. 337-346.

11. KSH (2000): A mezőgazdasági és erdőgazdálkodási számlarendszer kézikönyve (EAA \& EAF Rev. 1). Központi Statisztikai Hivatal, Budapest. p. 36.

12. Maácz M. (2013): DIT-ÚMVP III-IV. tengelyét érintő programmódosítási javaslatok, ppt előadás

13. Magda S. (szerk.) (2003.): A mezőgazdasági vállalkozások gazdálkodásának alapjai. Mezőgazdasági vállalkozások szervezése és ökonómiája I. Szaktudás Kiadó Ház, Budapest. pp. 51-68.

14. Magócs K. - Saád T. (2011): Félidőben az Új Magyarország Fejlesztési Program - Mi lett a fejlesztési források sorsa?, Vidék és Gazdaság 2011/ősz, Budapest

15. Nagy A (2016): A turizmus hatása a térgazdaság fejlődésére Magyarországon, Doktori értekezés, Szent István Egyetem, Gazdálkodás- és Szervezéstudományok Doktori Iskola, $188 \mathrm{p}$.

16. Nagy H. - Káposzta J. (2016): Interpretation of land-use system in Hungary in the context of rural development, Engineering for Rural Development 15: pp. 1330-1335.

17. Németh T. (2012): Darányi Ignác Terv - A Nemzeti Vidékstratégia Végrehajtási Keretprogramja (2012-2020), ppt előadás

18. Ritter, K. - Kassai, Zs. - Farkas, T. (2011): Importance of the LEADER programme in Hungarian rural areas facing globalization and agricultural decline. In: Annals of The Polish Association of Agricultural and Agribusiness Economists, 13 (6), pp. 205-210. ISSN 1508-3535.

19. Ritter, K. - Péli, L. - Péter, B. (2012): The role of agriculture and urban-rural connections in lagging rural areas of Hungary. Annals of Agricultural Economics and Rural Development 99 (3) pp. 27-33. ISSN 0080-3715

20. Szakál F. (2000.): A vállalat, mint gazdasági rendszer In: Buzás Gyula - Nemessályi Zsolt - Székely Csaba (2000): Mezőgazdasági üzemtan I. Mezőgazdasági Szaktudás Kiadó, Budapest. pp. 31-32.

21. Tánczos T., Nagy H., Kollár K. (2012): Territorial analysis on the social and economic development of the Hungarian micro regions, Acta Regionalia et Environmentalica 9:(1) pp. 12-16. ISSN: 1336-5452 